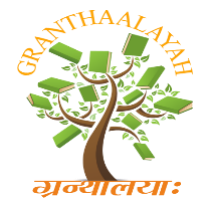

\author{
INTERNATIONAL JOURNAL OF RESEARCH - \\ GRANTHAALAYAH \\ A knowledge Repository
}

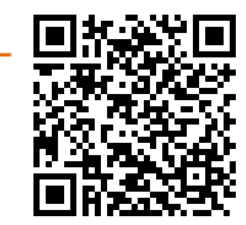

Science

\title{
EFFECTS OF SEED PRIMING WITH SODIUM CHLORIDE ON SEEDLING PERFORMANCE OF COMMON BEAN (PHASEOLUS VULGARIS L.) UNDER GREEN HOUSE CONDITION
}

\author{
Roba Tufa ${ }^{1}$, Jima Nego ${ }^{2}$ \\ ${ }^{1,2}$ Department of Horticulture and Plant Sciences, Jimma University College of Agriculture and \\ Veterinary Medicine(JUCAVM), P.O.Box 307,Jimma, ETHIOPIA
}

DOI: https://doi.org/10.29121/granthaalayah.v4.i6.2016.2654

\section{ABSTRACT}

This study was conducted at Jimma University College of Agriculture and Veterinary Medicine (JUCAVM) under controlled environmental conditions of greenhouse to determine the effects of different concentration of sodium chloride ( $\mathrm{NaCl}$ ) on germination and seedling growth of Phaseolus vulgaris L. Five concentrations of sodium chloride (o mol(distilled water), $0.1 M, 0.2 M, 0.3 M$ and $0.4 M$ ) with one control treatment of un-primed seeds were laid out in completely randomized design (CRD) with three replication. Data were collected on standard germination, Rate of germination, Seedling height, Shoot length, Root length and Vigor index. The result revealed that different $\mathrm{NaCl}$ concentrations statistically $(p \leq 0.05)$ affected standard germination, Rate of germination, Seedling height, Shoot length and Vigor index I of common bean crop. The highest value of all these parameters were obtained from seed primed with $0.1 \mathrm{M} \mathrm{NaCl}$ as well as when the seed primed with distilled water. However, the lowest values of these parameters were recorded on the seed primed with the highest concentration (0.4M) of $\mathrm{NaCl}$ and un-primed seed. More of the examined parameters were decreased with increasing of $\mathrm{NaCl}$ concentration. In conclusion, priming seed with $0.1 \mathrm{M}$ of $\mathrm{NaCl}$ concentration enhanced germination and seedling performance of common bean.

Keywords:

Common bean, concentration, Sodium Chloride, Priming.

Cite This Article: Roba Tufa, and Jima Nego, "EFFECTS OF SEED PRIMING WITH SODIUM CHLORIDE ON SEEDLING PERFORMANCE OF COMMON BEAN (PHASEOLUS VULGARIS L.) UNDER GREEN HOUSE CONDITION" International Journal of Research - Granthaalayah, Vol. 4, No. 6 (2016): 222-228.

\section{INTRODUCTION}

The common bean (Phaseolus vulgaris L.) also known as haricot bean has evolved from a wild growing vine distributed in the highlands of Central America and the Andes into a major leguminous food crop growing worldwide in a broad range of environments and cropping 
systems (Gepts and Debouck, 1991). It is assumed that beans were introduced to Ethiopia in the 16th century by the Portuguese (Imru, 1985). Common bean is adapted to areas with altitudes ranging from sea level to nearly 3000 meter above sea level, m. a. s. 1. (CIAT, 1986b). However, it does not grow well below $600 \mathrm{~m}$. a. s. 1. due to poor pod set caused by high temperature (Cobley, 1976). Suitable production areas of bean in Ethiopia has been indicated as areas with altitude between 1200-2200 m. a. s. 1., mean maximum and minimum temperature of less than 32 ${ }^{\circ} \mathrm{C}$ and greater than $10{ }^{\circ} \mathrm{C}$, respectively with a rainfall ranging from 350 to $700 \mathrm{~mm}$ well distributed over 70-90 days (Imru,1985; Amare and Haile, 1989 ). Phaseolus is cultivated all over the world or continents except Antarctica, under very diverse cultivation conditions. Among the Asian countries, China, Iran, Japan, and Turkey are the major producers of the common bean (Singh, 1999).

At the time of their growth crop plants are usually exposed to different environmental stresses which limit their growth and productivity. Among these, salinity and drought are the most factors that affect plant growth. Salinity has been estimated that more than $20 \%$ of all cultivated lands around the world contain salt levels high enough to cause salt stress to crop plants (Moud M., Maghsoudi K., (2008). At high enough concentration of salt and in saline environment, adaptation of plants to salinity during germination and early seedling stages is crucial for the establishment of species. Seedlings are the most vulnerable stage in the life cycle of plants and germination determines when and where seedling growth begins (Lianes A., Reinoso H., Luna V.,(2005). Salinity reduces the ability of plants to utilize water and reduce rate of growth, as well as changes in plant metabolic processes (Munns, 1993; Munns, 2002). Furthermore, it decreases plant growth, seedling performance and yield potential, depending on the plant species, salinity levels, and ionic composition of the salts (Yadav et al.,2010). Soil salinity is a widespread environmental problem and one of the important factor in limiting agricultural productivity.

During their growth, crop plants are usually exposed to different environmental stresses which limit their growth and productivity. Among these, salinity and drought are the most severe ones. In saline environment, adaptation of plants to salinity during germination and early seedling stages is crucial for the establishment of species. Seedlings are the most vulnerable stage in the life cycle of plants and germination determines when and where seedling growth begins. There are contradictory reports in the literature as to the relative sensitivity of germination and seedling growth to salt stress and limited researches has been conducted in this regard, which needs further research. Therefore, the objective of this study was to determine the effects of different concentration of sodium chloride $(\mathrm{NaCl})$ on germination and seedling growth of common bean crop under Jimma condition.

\section{MATERIALS AND METHODS}

Description of Study Area: The study was conducted at Jimma University college of Agriculture and veterinary medicine in green house condition during 2016 under irrigation. The area is located in Oromia Region, Jimma zone of south western part of Ethiopia which is located at $7^{0} 33^{\prime}$ lattitude and $36^{\circ} 57 \mathrm{E}$ longitudes and the altitude of 1710 meter above sea level (m.a.s.l). The area receives an annual rainfall of $1500 \mathrm{~mm}$. The maximum and the minimum temperature of the area is $26.8^{\circ} \mathrm{C}$ and $11.4^{\circ} \mathrm{c}$ respectively. The soil of the area is characteristically reddish brown clay soil with PH from 5.07 to 6. 
Experimental material: Local variety of Common bean seed was used as planting material for this study. Water and Sodium Chloride were used as priming media.

Treatments and Experimental Design: The treatments consisted of five concentrations of Sodium Chloride ( $0.0 \mathrm{M}$ concentration (distilled water), $0.2 \mathrm{M}, 0.2 \mathrm{M}, 0.3 \mathrm{M}$, and $0.4 \mathrm{M}$ of $\mathrm{NaCl}$ ) for priming, with one control treatment of un-primed seeds. The experiments were laid out as completely randomized design (CRD) replicated three times. Thus, there were $5 \times 3$ treatments, which were replicated three times, resulting in 15 experimental units. The un-primed seeds were used as control with three replications alone. Therefore, totally 18 experimental units were established.

\section{EXPERIMENTAL PROCEDURES}

Preparation of NaCl Solution: The solutions were prepared by dissolving 0.00(hydro-priming), $5.85,11.7,17.55$, and $23.4 \mathrm{~g}$ of $\mathrm{NaCl}$ in 1 litre of distilled water respectively and used for priming.

Seed priming and re-drying: Prior to the hydro-priming and $\mathrm{NaCl}$ priming treatments, the moisture contents of the seeds have been determined using oven dry method (ISTA, 1985) and brought to the same constant moisture. Seeds were fully immersed in the priming media on Petri Dishes for 12 hours. All seeds were removed from the priming media at the same time. Primed seeds were washed out and dried under shade back to the original moisture content prior to sowing, and sown in germination pots each of which contained 20 seeds. The Pots were lined for placing the seeds in a uniform distribution for germination and all seedlings per pot were used for analysis. Data that included standard germination percentage, rate of germination, and vigour test, Seedling heights, and seedling dry weights were measured.

\section{DATA COLLECTION AND ANALYSIS}

The following data were collected:

Germination percentage: Describes how many seeds of a particular plant species, variety or seed lot are likely to germinate. It is usually expressed as a percentage and germinated seeds were counted daily according to the seedling evaluation procedure described by ISTA, 1985. The number of germinated seeds were recorded every days (AOSA, 1990). Fifteen days after planting, the standard germination (SG) was calculated using the following formula.

$\mathrm{SG}(\%)=$ Number of germinated normal seedlings $\mathrm{x} 100$

Total number of planted seeds

Rate of germination: It is the ratio of number of seeds germinated on each day to the day of counting. From the date of emergence, seedlings were recorded or counted and the seedlings' stunted primary roots were considered as abnormally germinated (ISTA, 2011). The mean germination time (MGT) was calculated to assess the rate of germination (Ellis and Roberts, 1981) using the following formula: 
$\operatorname{MGT}=\frac{\sum(\mathrm{Dn})}{\sum \mathrm{n}}$ counting.

Where $n$ is the number of seeds germinated on each day and $D$ is the day of

Shoot length (cm): Five normal seedlings in each pot were randomly selected for the measurement of shoot length on $15^{\text {th }}$ day. After watering the pot, the seedlings were carefully selected and pulled out without damaging shoots. The shoot length measured from the base to tip of the longest shoot and mean shoot length was express in centimeters.

Seedling height (cm): The summation of shoot length and root length and it is determined by centimeter. Seedling vigour: The lengths of five randomly selected seedlings per pot were measured in $\mathrm{cm}$ using a ruler. Seedling vigour was determined by two methods:

Vigour Index I= Germination Percentage x Seedling Length $(\mathrm{cm})$ (shoots length + root length).

Vigour Index II= Standard Germination Percentage $\mathrm{x}$ seedling dry weight $(\mathrm{g})$.

\section{RESULTS AND DISCUSSIONS}

\section{GROWTH PARAMETERS}

Analysis of Variance showed that there was highly significant $(\mathrm{p}<0.001)$ differences among standard germination (SG) due to concentration of $\mathrm{NaCl}$ (Table.1). The maximum values of standard germination $(100 \%)$ were recorded from common bean seed primed with distilled water, $0.1 \mathrm{M}$ and $0.2 \mathrm{M}$ of $\mathrm{NaCl}$. However, these results were statistically similar with the seed primed with $0.3 \mathrm{M}$ of $\mathrm{NaCl}$. On the other hand, the lowest values of $\mathrm{SG}$ were recorded from control (un-primed seed) $(88.33 \%)$ and $0.4 \mathrm{M}((95 \%)$ concentration of $\mathrm{NaCl}$ respectively (Table 2). This result indicated that priming common bean seed with the highest $(0.4 \mathrm{M})$ concentration of $\mathrm{NaCl}$ negatively influenced standard germination of Common bean crop. Generally, standard germination consistently decreased as concentration of $\mathrm{NaCl}$ increased. This may be attributed to the salinity effect of the $\mathrm{NaCl}$ salt resulting in burning effect and disabling of the seedling to absorb water.

The result of this study agreed with the idea Kaymakanova, 2009 who reported that $\mathrm{NaCl}$ stress had a negative impact on SG. Similarly, the results of this study were agreed with the finding of Bayuelos et al., 2002; Eroglu, 2007; Duros and Magne 2008 indicating that the seed exposed to high concentration of $\mathrm{NaCl}$ was strongly affected germination of the crop. In addition to the ideas of these authors, Shokohifard et al, 1989 also pointed that salinity stress negatively affects seed germination, either osmotically through reduced water absorption or ionically through the accumulation of $\mathrm{Na}^{+}$and $\mathrm{Cl}^{-}$, causing an imbalance in the nutrient uptake and toxicity effect. 
Table 1: Mean square values for germination, rate of germination, seedling growth and vigour of common bean crop

\begin{tabular}{|c|c|c|c|c|c|c|}
\hline \multirow{2}{*}{$\begin{array}{l}\text { Source } \\
\text { Variation }\end{array}$} & \multirow{2}{*}{ of Df } & \multicolumn{5}{|c|}{ Mean squares } \\
\hline & & SG & RG & $\begin{array}{l}\text { Shoot } \\
\text { Length }\end{array}$ & Seedling height & $\begin{array}{l}\text { Vigor } \\
\text { index-1 }\end{array}$ \\
\hline Treatment & 5 & $64.72 * * *$ & $0.44^{\mathrm{NS}}$ & $19.44^{*}$ & $33.95^{*}$ & $806053 * *$ \\
\hline Error & 10 & 6.9444 & 0.28372 & 4.9494 & 10.8356 & 96189 \\
\hline
\end{tabular}

$\mathrm{CV}$ indicates Coefficient of variation, $\mathrm{DF}=$ Degrees of freedom, $\mathrm{SG}=$ standard germination, $\mathrm{RG}=$ rate of germination, ${ }^{*}=$ significant at $5 \%$ probability level, $* *=$ highly significant at $\mathrm{p} \leq 0.01$, and $* * *=$ highly significant at $\mathrm{p} \leq 0.001$.

Table 2: Germination Percentage, Shoot length, Seedling height and Vigor idex-I of Common bean Seed as affected by concentration of Sodium Chloride $(\mathrm{NaCl})$

\begin{tabular}{lllll}
\hline $\begin{array}{l}\text { Treatments } \\
(\mathrm{NaCl} \text { concentration })\end{array}$ & $\begin{array}{l}\text { Standard } \\
\text { Germination }(\%)\end{array}$ & $\begin{array}{l}\text { Shoot } \\
(\mathrm{cm})\end{array}$ & $\begin{array}{l}\text { Length } \\
\text { heedling } \\
\text { height }(\mathrm{cm})\end{array}$ & Vigor Index I \\
\hline $0.0 \mathrm{M}\left(\mathrm{H}_{2} 0\right)$ & $100 \mathrm{a}$ & $29.23 \mathrm{ab}$ & $55.37 \mathrm{ab}$ & $5536.7 \mathrm{ab}$ \\
$0.1 \mathrm{M}$ & $100 \mathrm{a}$ & $32.36 \mathrm{a}$ & $56.77 \mathrm{a}$ & $5676.7 \mathrm{a}$ \\
$0.2 \mathrm{M}$ & $100 \mathrm{a}$ & $29.26 \mathrm{ab}$ & $53.30 \mathrm{abc}$ & $5330.0 \mathrm{ab}$ \\
$0.3 \mathrm{M}$ & $98.33 \mathrm{ab}$ & $27.86 \mathrm{bc}$ & $51.87 \mathrm{abc}$ & $5097.8 \mathrm{~b}$ \\
$0.4 \mathrm{M}$ & $95 \mathrm{~b}$ & $25.03 \mathrm{c}$ & $47.50 \mathrm{c}$ & $4511.3 \mathrm{c}$ \\
Un-Primed & $88.33 \mathrm{c}$ & $26.50 \mathrm{bc}$ & $50.47 \mathrm{bc}$ & $4451.3 \mathrm{c}$ \\
seed(control) & & & & \\
\hline LSD & 4.69 & 3.96 & 5.86 & 551.74 \\
CV & 2.72 & 7.84 & 6.26 & 6.08 \\
Significant Level & $* * *$ & $*$ & $*$ & $* *$ \\
\hline
\end{tabular}

Means within the same column followed by different letter are significantly different at $P \leq 0.05$

\section{GROWTH OF SEEDLING}

Analysis of variance result was showed that there were significant $(\mathrm{p} \leq 0.05)$ differences on shoot length and seedling height due to concentration of $\mathrm{NaCl}$ (Table 1). The maximum value $(32.36 \mathrm{~cm})$ of Shoot Length was recorded from common bean seed primed with $0.1 \mathrm{MNaCl}$. However, this result was statistically similar with seed primed with distilled water and $0.2 \mathrm{M}$ of $\mathrm{NaCl}$ salt while the lowest value was recorded from the seed primed with the highest concentration ( $0.4 \mathrm{M})$ of $\mathrm{NaCl}$ salt (Table 2). The results of this study indicated that the growth of common bean can be affected by concentration of $\mathrm{NaCl}$ (Table2). Consistently as concentration of $\mathrm{NaCl}$ increased shoot growth decreased. Generally, salinity might be affect common bean seedling growth by disturbing transport system and metabolic processes. The result of this study was agreed with the idea pointed by Munns, 1993; Munns, 2002 reporting that Salinity reduces the ability of plants to utilize water and reduce rate of growth, as well as changes in plant metabolic processes. Furthermore, it decreases plant growth, seedling performance and yield 
potential, depending on the plant species, salinity levels, and ionic composition of the salts (Yadav et al., 2010).

The maximum value $(56.77 \mathrm{~cm})$ of seedling height was obtained from the seed primed with the lowest concentration $(0.1 \mathrm{M})$ of $\mathrm{NaCl}$ salt. However, this result is statistically on par with the seedling height obtained from the seed primed with distilled water, $0.2 \mathrm{M}$ of $\mathrm{NaCl}$ concentration and $0.3 \mathrm{M} \mathrm{NaCl}$. On the other hand, the shortest seedling was recorded on the seed primed with the highest concentration $(0.4 \mathrm{M})$ of Nacl salt followed by control treatment (un-primed seed).

\section{VIGOR INDEX}

Highly significant $(\mathrm{p}<0.01)$ differences were observed among treatments of sodium chloride for vigour index I (Table 1). Increasing the concentration of the sodium chloride salt resulted in significantly decreasing trend in vigour Index I. Thus, the highest vigour index I (5676.7) was recorded for seedlings raised from seeds primed with $0.1 \mathrm{M} \mathrm{NaCl}$. However, the value of vigour index I of seedlings raised from seeds primed with $0.1 \mathrm{M} \mathrm{NaCl}$ was in statistical parity with the value of seedling vigour index I of the seedling raised from the seed primed with distilled water and $0.2 \mathrm{M} \mathrm{NaCl}$. On the other hand, the lowest value of vigour index I were obtained for unprimed seed (control) and the seed primed with the highest concentration $(0.4 \mathrm{M})$ of $\mathrm{NaCl}$ salt (Table 2). In agreement with the result of this study, Khajeh-Hosseini et al. 2003 and Ungar 1996 indicated that seedling length which contributes highly for the vigour index I decreased significantly with increased salinity.

\section{CONCLUSION}

The results of this study revealed that different concentration of $\mathrm{NaCl}$ significantly influenced most parameters evaluated. Accordingly, the seedling raised from the seed primed with $0.1 \mathrm{M}$ of $\mathrm{NaCl}$ was superior as compared to other treatments with regard to standard germination, Seedling height, Shoot length as well as Vigor index-I. Whereas the seed primed with the highest concentration $(0.4 \mathrm{M})$ of $\mathrm{NaCl}$ and un-primed seed (control) showed poor performance of common bean with regard to standard germination, seedling growth (shoot length and seedling height) and vigour index I.

\section{ACKNOWLEDGMENTS}

The authors would like to thank Jimma University College of Agriculture and Veterinary Medicine (JUCAVM) for funding the research and providing all the necessary facilities required for the research.

\section{REFERENCES}

[1] Amare Abebe and Haile Kefene, 1989. Country reports of Eastern Ethiopia. pp. 110-121. In: Proceedings of a Workshop on Bean Varietal Improvement in Africa, Maseru, Lesotho. 30 Jan.-2 Feb. 1989. CIAT African Workshop.

[2] AOSA (1990). J. Seed Technol. 12: 1-112. Rules for Testing Seeds, USA. Ayers R, Westcot W (1985). Water quality for agriculture. Irrigation and Drainage Paper No. 29 (Revised), FAO, Rome, Italy, 174 p. 
[3] Bayuelos J, Craig R, Lynch J (2002). Salinity tolerance of Phaseolus species during germination and early seedling growth. Crop Sci. 42:1584-1594.

[4] CIAT (Centro International de Agricultural Research Tropical), 1986b. The cultivated species of Phaseolus: Study guide to be used as supplement to the audio tutorial unit on the same topic, Cali, Colombia, CIAT.

[5] Cobley, L. S., 1976. An Introduction to the Botany of Tropical Crops. 2nd (ed.). Longman Group Limited, London.

[6] Duros LM Magne C (2008). Effect of salinity and chemical factors on seed germination in the halophyte Crithmum maritimum L. Plant Soil, 313:83-87.

[7] Ellis RA Roberts EH (1981).The quantification of ageing and survival in orthodox seeds. Seed Sci. Technol. 9: 373-409.

[8] Eroglu I (2007). Effects Of Salt Stress On The Seed Germination And Seedling Growth Of Some Bean (Phaseolus vulgaris L.) Cultivars. Ege University Graduate School of Natural and Applied Sciences, Biology Department, PhD Thesis, 77p.

[9] Gepts, P. and D. Debouck, 1991. Origin, domestication and evaluation of common bean (Phaseolus vulgaris L.). pp. 7-53. In: Van Schoonhoven, A. and O. Volysest, (ed.). Common beans, Walling ford.

[10] Imru Assefa, 1985. Bean production in Ethiopia. pp. 15-38. In: Regional workshop on potential for field beans (Phaseolus vulgaris L.). In West Asia and North Africa Proceedings of a Regional Workshop in Aleppo, Syria, 21-23 May, 1983. Center International de Agricultura Tropical, Cali, Colombia.

[11] ISTA (2011). Rules Proposals for the International Rules for Seed Testing 2011 Edition. International Seed Testing Association.53p. Secretariat, Zürichstrasse 50, CH-8303 Bassersdorf, Switzerland.

[12] ISTA (International Seed Testing Association), 1985. International rules for seed testing. Seed Science and Technology, 13: 1299-355.

[13] Khajeh-Hosseini M, Powell AA, and Bingham IJ (2003). The interaction between salinity stress and seed vigour during germination of soybean seeds. Seed Science and Technology, 31(3): 715-725.

[14] Lianes A., Reinoso H., Luna V.,(2005) World J. of Agricultural Sciences 1(2), 120-128.

[15] Moud M., Maghsoudi K.,(2008) World J. of Agricultural Sciences 4(3), 351-358.

[16] Munns $R$ (1993). Physiological processes limiting plant growth in saline soils: Some dogmas and hypotheses. Plant Cell Environ. 16: 15-24.

[17] Munns R. (2002); Comparative physiology of salt and water stress. Plant Cell Environ. 25:239-250.

[18] Shokohifard G, Sakageim KH, Matsumoto S (1989). Effect of amending materials on growth of radish plant in salinized soil. d. Plant Nutr., 12: 119-1294.

[19] Singh SP (1999). Developments in Plant Breeding: Common Bean Improvement In The Twenty-First Century. Kluwer Academic Publishers, The Netherlands, $409 \mathrm{p}$.

[20] Yadav SS, McNeil DL, Redden R, Patil SA (2010). Climate Change and Management of Cool Season Grain Legume Crops. Springer, Dordrecht; Heidelberg, 460 p. 